\title{
Tolerance and Human Resources in Science and Technology in East Asia
}

\author{
Stephan Si-Hwan Park
}

\begin{abstract}
This article tries to pursue three goals: first, how can a hard-to-define cultural concept such as tolerance in society be measured? Second, is it possible to draw conclusions about the tolerance level of a nation on the basis of an analysis of web search behaviour? And third, is there a relationship between the tolerance level in East Asian societies and their ability to attract highly qualified knowledge workers? Taking as its starting point Richard Florida's claim that a high tolerance level in society represents an essential pull factor for attracting the most sought-after people in the world, this article analyses and interprets web search behaviour among Google users residing in Japan, Korea and China in order to identify issues related to tolerance in East Asia.
\end{abstract}

Keywords: tolerance, creative class, East Asia

Park, Stephan Si-Hwan. "Tolerance and Human Resources in Science and Technology in East Asia." In Vienna Journal of East Asian Studies, Volume 3, eds. Rudiger Frank, Ingrid Getreuer-Kargl, Lukas Pokorny and Agnes Schick-Chen. Vienna: Praesens Verlag, 2012, pp. 109-138. https://doi.org/10.2478/vjeas-2012-0004 


\section{Introduction}

We asked for workers, and human beings came. (Max Frisch)

East Asia has become a widely used synonym for rapid economic growth and transformation. The academic interest in explaining the speed and effectiveness of such an economic metamorphosis from a rural and underdeveloped to an advanced and high-technology region has been tremendous. Japan's Nikkei Business Daily reported that according to an International Monetary Fund forecast, by 2014 the East Asian nominal GDP is expected to reach US\$17.34 trillion, approaching the United States' US\$17.41 trillion (Letzing 2009). Extrapolating from the current economic performance of all major economic regions and projecting it to the future draws a clear picture: East Asia will surpass the United States as the global powerhouse within the next years (Letzing 2009). It seems that the continuation of the East Asian miracle is inevitable.

Not everybody agrees. According to Richard Florida, the East Asian societies need to catch up on one essential feature for sustainable economic growth in a highly globalised world: tolerance (Florida 2010; Florida, Mellander and Qian 2008: 32). Without tolerance, highly skilled and creative people, who are a prerequisite for economic growth in any region of the world, would rather live and work in places where they can express themselves freely, pursue their desired lifestyle and just be themselves without feeling judged by society (Florida 2004: 67-82). But this is not the whole story. Florida argues that only the dynamic and interdependent interplay between the three ' $T$ 's of economic growth - tolerance, talent and technologygenerate, enhance and sustain economic development in a region (Florida 2004: 249-267). Referring to renowned academics and Nobel Prize laureates such as Robert M. Solow, who proved a clear connection between technology and growth (1956: 65-94), as well as Robert E. Lucas Jr., who showed that a high level of human capital corresponds to a high economic growth rate (1988: 3-42), Florida identifies tolerance as the essential link between technology and talent (2007: 66-93). A high level of tolerance in a society raises the ability of a place to attract talented people from various fields, which in turn leads to the creation of more innovative technologies and finally results in economic growth in the long term. In Florida's concept of the 'creative class' he argues that today there is a fierce global competition among advanced countries for talent. Members of the creative class are the global workers who are in the fortunate position of being compensated monetarily for their creative input (Florida 2005a: 4). Starting from the assumption that human creativity is limitless, Florida claims that the key to economic growth is enabling and unleashing that potential. This requires an open culture, a culture that allows people to be themselves, approves various forms of family and human identity (Florida 2007: 66-93). Basically, this is a culture in which any group of people independ- 
ent of nationality, gender or sexual orientation can live, work, and study without being discriminated against.

As a trained economist, Florida stresses in his theory the economic impact of a highly qualified and creative workforce on regions, nation-states and the world in general. However, since Florida's theory deals with a wide range of different issues such as sociology, geography, migration policy, urban planning, etc., it is hard to narrow down the creative class concept to one or two specific academic disciplines. Likewise, both positive and negative reactions to his theory have come from different representatives from various academic fields. Perttu Salmenhaara, for instance, whose study is social policy issues, considers Florida's concept as nothing genuinely original because governments and companies has been trying to attract experts for decades with special treatment and monetary rewards (2006: 235). Furthermore, he sees two major problems that come with Florida's theory: first, the data presented might be considered insufficient and should be supported by qualitative data, and second, instead of making counterparts out of regions such as Silicon Valley and parts of Shànghăi 上海 or Mumbai, he created a global ranking on creative competitiveness out of nations. Although Florida's theory contains strong post-national elements and stresses the importance of the societal elites that are actually free from these boundaries, the ranking by Florida suggests that the world is formed by existing nation-states. Salemenhaara identifies this as a logical mistake on Florida's part (2006:235). McGregor, specialising in public and environmental affairs, agrees with Florida that creative occupations exist but argues that Florida's claim is incorrect that ordinary jobs and 'non-creative' jobs cannot benefit from the products and services that are produced by the creative workforce (2006: 751). Naylor, on the other hand praises Florida's theory insofar that it provides new ways to conceptualise many of the rapid changes taking place in today's workplaces and economies (2003: 378). Bhagat even considers Florida's work as already a classic reference for researchers in the field of sociology, industrial psychology and organisational sciences (2004: 325).

Applying Florida's three Ts concept to the East Asian context, it can be said that Asian countries do well in the first two Ts of economic growth technology and talent, but in terms of the third $\mathrm{T}$, tolerance, discrimination issues have been persistent in all three East Asian states. Japan and Korea ${ }^{1}$ are on the forefront in the technology field with a fast advancing China ${ }^{2}$ following closely behind. The whole region offers a population highly devoted to education (Wang 2004: 429-447), which consequently results in a vast pool of high-level human capital on which the economy can draw. With regard to tolerance, frequent coverage in the media (Glionna 2009; Azad 2006; Jia 2007) about cases of discrimination against foreigners and women

1 'Korea' refers to the Republic of Korea.

2 'China' refers to the People's Republic of China. 
suggest that East Asian societies might have to catch up. According to Florida, for East Asia to be in the front of innovation requires the region to start attracting the world's sharpest and most creative minds. To make this happen, the East Asian countries need to raise their tolerance level significantly (Florida 2010; Florida, Mellander and Qian 2008: 32).

Florida conducted extensive empirical research on capturing the creative class structure in the United States and extended his work into a cursory overview of the world's creative talent magnets. In his book The Flight of the Creative Class, published in 2007, he presented the 'global creative index' (GCI), a ranking of the major 45 creative nations in the world. Based on a number of different measures for each of the three Ts, the GCI placed Japan second behind Sweden but before the United States. Korea held 16th place, while China ranked 36th (Florida 2007: 274-278). However, his ranking does not possess any explanatory power. His model does not provide any insight into the interrelations between tolerance, talent and technology, nor does it explain why Japan is ahead of Korea and China but behind Sweden, placed first. In addition to the explanatory weakness of Florida's basically reasonable approach, there are hardly any publications on tolerance in Japan, China and Korea, far less any comparative analysis on East Asia's tolerance level as a whole. This article introduces and tests an alternative approach in assessing the tolerance level of a society. Inspired by Richard Florida's work, which suggests a connection between tolerance and a region's ability to attract global talent, in this instance to the most successful high technology-producing areas in the United States, I hypothesise for the East Asian region that, because of the lack of tolerance in East Asian societies, global talents and highly qualified foreigners choose to live and work in more tolerant places, outside of East Asia.

On the basis of the above hypothesis, a number of central research questions arise:

- What is the definition of tolerance? How can tolerance be measured?

- What is the tolerance level in the major East Asian countries? How has it changed over time?

- How is tolerance regionally distributed?

- Is there an East Asian pattern of tolerance?

- What do the East Asian governments do to attract global talents?

- How many highly qualified foreigners live and work in East Asia? Are there enough talented people to sustain economic growth in the long run?

- Does the continuation of the 'East Asian miracle' depend on highly qualified foreigners?

- Is there a relation between the tolerance level of a society and a country's ability to attract global talent? 
Shedding light on these research questions and checking the hypothesis are the aims of this work.

\section{Terms and definitions}

\section{Tolerance}

The term 'tolerance' is a relational term. Its appearance, history and impact derive from the effort to arrange relations among persons normatively (Schreiner and Besier 1997: 446). According to Müller and Halder, 'tolerance describes the acceptance of others with different beliefs, behaviours and customs' (1973:169). In other words, tolerance is the acceptance of the egality of different individuals (Teichert 1996: 316-318. The term can be found with no consistent meaning in the fields of law, political science, sociology, and philosophy. In each case, tolerance stands in relation to ways and rules of handling conflicts in social systems (Teichert 1996: 316318). In the political and societal sphere, tolerance is one answer of a closed society and its mandatory value system towards minorities with different convictions and beliefs which cannot be integrated into the ruling system (Müller and Halder 1973: 169). Tolerance also protects people whose opinions differ from those of the majority in society, from repression and is thus considered as a condition for humanity (Müller and Halder 1973: 169). The modern constitutional state certifies tolerance as an indispensible political and social principle that defines discrimination as an unconstitutional action, requires equal rights, and obligates states to follow democratically agreed norms on proceedings and decisions (Benda 2001: 2147-2148). The history of the term was determined considerably through the tense relationship between passive patience and active toleration, between the ability to endure suffering and the acceptance of others with their respective differences (Schreiner and Besier 1997: 446).

Another concept that is used interchangeably with tolerance in daily life is cultural openness within a society. According to Suro (2011), cultural openness seems to have gone through a conceptual transition from a former static to a more dynamic view. Whereas previously the evaluation of cultural openness in society was more or less understood as the number of discrete groups and the number of people that could be assigned to each of them, the new and dynamic conception of cultural openness takes into account the number of ways in which people from different groups exchange influences and the quality of the contact. This article's conception of tolerance and discrimination respectively tries to include both the static and the dynamic aspects of cultural openness within society.

From an analytical and philosophical perspective, tolerance stands for an attitude and an experience that is only required in a conflict (Forst 2003: 12). The remark- 
able quality of tolerance is that tolerance is not capable of solving the conflict but only of easing it. Conflicting belief systems, interests and practices continue to exist but lose their destructive power. Tolerance claims that co-operation is possible despite dissent (Forst 2003: 12). Tolerance is not just a specific demand in social conflicts but is itself the subject of controversies. Both in the past and in the present, the term has not only been obscure but raises emotional disputes. It is possible that one and the same policy or action can be viewed by one group of people as tolerant and by another as intolerant. The debate becomes even more intense when the role of tolerance is discussed. Some share the opinion that tolerance itself may not be a good thing to pursue in society. Whereas for some persons tolerance is a virtue provided by God, which is demanded by reason, ethics and wisdom, others view tolerance as a condescending, paternalistic and potentially repressive act; for the one side, it is the expression of self-assurance and firmness of character, for the other, an attitude of insecurity and weakness; for the first side, it shows respect for others and appreciation for the different, for the other, an attitude of indifference, ignorance and separation (Forst 2003:14). Throughout history conflicts have existed in which tolerance seemed to offer a solution. Nowadays, tolerance has its place on the agenda not only within societies but also between states and all kinds of regimes. Governmental institutions and non-governmental organisations alike debate how far tolerance should go.

\section{Discrimination}

According to the United Nations, 'discriminatory behaviors take many forms, but they all involve some form of exclusion or rejection'. (United Nations Global Teaching and Learning Project, 2010)

Turning to the different forms that discrimination can possibly take, the most common ones are discrimination against other races or ethnicities, discrimination against women, and discrimination against people based on their sexual orientation. Another, publicly less-known form of discrimination is age discrimination, which describes discrimination against individuals or groups because of their age (Nelson 2002: 14). In Japan for instance, age discrimination can be found in job announcements which, in addition to qualification requirements, specify that only people under a certain given age are eligible to apply for a job position. Age discrimination thus can frequently be observed among middle-aged people, who have more difficulty in finding a job and therefore show a higher risk of becoming long-term unemployed (Shimizu 2002). The semantic interjection of all the different manifestations of discrimination is the element of exclusion or rejection. In other words, a group of people who are experiencing a form of discrimination is excluded or restricted from opportunities that are available to other groups (Giddens et al. 2009: 324). In the 
context of highly qualified immigrants, discrimination happens when an equally qualified foreigner does not receive the same benefits or remuneration as a native co-worker. On a broader scale, discrimination against foreigners implies that they are excluded from society to the extent that natives avoid social interaction with them altogether or all contact outside of work. If we compare the definitions of tolerance and discrimination with each other, it is not quite correct to consider discrimination as the opposite of tolerance.

The concepts of tolerance and discrimination are closely related to each other, but whereas tolerance basically means the acceptance of different groups of people and thus implies some form of inactivity, discrimination indicates actual behaviour towards an individual or certain group of people. Consequently, discrimination can be seen as an active form of intolerance, which contributes to the reduction of tolerance in society.

\section{Highly qualified immigrant/foreigner}

For the purpose of establishing a relationship between tolerance and a country's ability to attract global knowledge workers to East Asia, a definition of this group of professionals is needed. Although use of the phrase 'the best and the brightest', referring to highly qualified immigrants, has experienced some inflation as a slogan in public and policy discourses in recent years, a review of the international academic and policy literature indicates that there is no consistent definition or measurement of highly skilled migrants (Batalova and Lowell 2006: 86) According to Batalova and Lowell, the reasons for this gap in the literature fall predominantly into two groups: data-related and conceptual. Research on the mobility of global knowledge workers in general remains difficult to ascertain, in part due to the absence of appropriate data. Population censuses and labour force surveys are the most readily available data sources; however, they lack crucial information about immigrants such as their legal status, the degree of return migration or the place where they obtained their education (Batalova and Lowell 2006: 86). Another reason that researchers are confronted with obstacles in studying the migration of a skilled workforce is of a methodological and conceptual nature. Recognition of the qualifications of skilled and qualified persons varies across countries. Furthermore, the terms 'skilled worker', 'highly skilled worker' and 'professional' are used interchangeably in various contexts (Batalova and Lowell 2006: 86).

The most fundamental definition of a highly skilled worker is a person who has obtained a tertiary education, meaning adults who have completed at least a college degree or more. On the one hand, while acknowledging that there is a wide range of occupations that require formal education and training, such as medical doctors or lawyers, there is still a considerable number of highly skilled and successful indi- 
viduals who have not attended college or university. On the other hand, relying solely on occupational characteristics does not guarantee that all people with college education or above are included (Batalova and Lowell 2006: 87). Bouvier and Simcox found that 31 percent of native-born engineers and 38.7 percent of mathematicians and computer scientists in the United States did not obtain a college degree in 1990, although formal qualification is normally required. Likewise, the numbers for foreign-born engineers and computer scientists were 14.5 and 23 percent (Bouvier and Simcox 1995: 429-444).

One attempt at establishing a global definition of a highly skilled worker, thus making research on the mobility of highly skilled workers internationally comparable, was conducted collaboratively by the OECD and the European Commission/Eurostat. The working definition, 'human resources in science and technology' (HRST), is based on two dimensions: qualification (tertiary level or better education) and occupation (training/employment in a science and technology occupation) (OECD 1995: 16). Individuals identified as HRST are those who satisfy one or the other of the two requirements:

1. They have successfully completed education to the third level in a science and technology (S\&T) field of study;

2. They have not formally qualified as such, but are currently employed in a S\&T occupation where the above qualifications are normally required

One crucial group of individuals who are not yet considered as HRST are international students who are currently enrolled in the fields of science and technology. They represent the resources of the future. A country's level of competitiveness rests not only on its ability to attract already educated or experienced HRST but also on its ability to attract international students in general and students in the S\&T field of study in particular. Studying in a foreign country is not only a life-changing experience which raises the soft power of the host country among international students to a substantial degree, it is also often the stepping stone for highly skilled immigration (Moroder 2001: 107). For our purpose of assessing the foreign base of HRST in East Asian countries more comprehensively, we expand the OECD definition by adding a third requirement for HRST:

3. International students who are currently enrolled at the third level in a science and technology field of study. 


\section{Research design: 'Google Insights for Search'}

In contrast to Florida, who measured tolerance by just combining two previously conducted surveys on culture and values, this work applies an alternative approach. In order to measure the awareness of tolerance in East Asian societies, it makes use of the analytical capabilities of Google, the most frequently used search website in the world today. Google's unquestioned position as the world's most popular search technology on the web has allowed it, to a limited extent, to predict future events and outcomes like influenzas and pandemics. Google announced recently that it is currently developing a tool that will be able to predict future stock market events (Niccolai 2010). Google provides a tool for registered users which analyses the interest in respective terms over the course of years, months and even days. The data are broken down by country and sub-region. The name of the tool is 'Google Insights for Search ${ }^{3}$, Google explains it as follows:

Google Insights for Search analyzes a portion of worldwide Google web searches from all Google domains to compute how many searches have been done for any term, relative to the total number of searches done on Google over time. The results from this tool have search volume with scaled value from 0 to 100 (Google 2012).

This tool has also been used by a number of researchers. Three remarkable examples are noteworthy: Scharkow and Vogelgesang suggested a new method for measuring aggregate issue salience by analysing data from search queries typed into Google Insights, compared with aggregate survey data from about 500 telephone interviews. They found substantial correlations between the two measurements (Scharkow and Vogelgesang 2009: 11-13). Hoffman and Novak compared data from Google Insights for Search with traditional brand-tracking metrics for monitoring brands. The authors found that search-trend data have real-world importance in terms of corresponding to brand-attitude awareness (Hoffman and Novak 2009: 3). Moreover, Askitas and Zimmermann used this tool to probe the relationship between search queries and the unemployment rate in Germany, and found that there is a robust correlation between keyword searches and unemployment rates (2009: 7-12).

Inspired by these remarkable findings, the question arises of how Google Insights for Search can be used in quantifying tolerance and the awareness of tolerance and discrimination in East Asian societies. Let us assume that foreigners who face incidents of discrimination tend to search for information on the web to find out if there are other people who are experiencing the same difficulties that they have. Generally, they use the Internet as a means for communication and information. Consequently, we may conclude that the interest intensity for the term 'discrimination' on the web seems to be a robust proxy for the actual awareness of the tolerance and

3 This search tool is available at http://www.google.com/insights/search. 
discrimination level of a country. These hypotheses must be even more accurate for HRST and international students, who must, because of their professional and social environment, show a high level of media and Internet literacy. For our purposes of measuring the awareness of tolerance in society, we cannot expect valid results for the term 'tolerance'. As we have seen in our attempt to define tolerance, it inherits a tremendous range of different conceptions in various contexts. For instance tolerance can be used in technical terms like measuring tolerance. Another, but for our purposes more promising term, which is closely related to our working definition of tolerance and is more specific at the same time, is discrimination. Discrimination is predominantly used in the context of society, and its derived sub-terms such as racial, ethnic, gender, sex, or sexual discrimination are all related to our concept of tolerance in society and will be listed as well in Google Insights for Search. To draw valid conclusions from the information Google Insights for Search provides, we need to compare theses statistics with real numbers of foreigners residing in the respective countries. Before we can start quantifying the awareness of tolerance and discrimination respectively, however, we must address three potential methodological constraints: 1. differences in access to Internet across regions and provinces, 2. Google's share in the search engine market, and 3. the personal characteristics of Google users.

\section{Access to the Internet}

According to the Asian Internet Market Report 2009 (Evans and Hulme-Jones 2009), the market in Asia continues to be dominated by the big players of North Asia, South Korea, Japan, and Hong Kong. In terms of absolute Internet user numbers, China (300 million) and India (95 million) maintain a strong role, despite their modest numbers in terms of user penetration. However, China surpassed the United States in 2008 to become the largest nation of Internet users in the world and was showing no signs of slowing down by the end of 2009. The Asian Internet market can be divided into three user-penetration groups. The top group is characterised by highly-penetrated markets in terms of users and subscribers. Complementary to this, they tend to have sophisticated, widely distributed broadband access facilities in place. According to the report, these countries from the top group are among the global leaders in broadband Internet. South Korea, with a user penetration of over 77 percent, tops the regional market list with a broadband subscriber penetration of 32 percent. Japan, with 74 percent user penetration, is slightly behind Hong Kong and Singapore, which both show a 75 percent rate. The countries in the second group show an approximate range in user penetration between 10 percent and 30 percent. They are currently expanding their Internet and broadband capabilities. However there is a clear gap (of almost 20 percent) to be overcome before they can be listed 
in the top list. China jumped from 16 percent penetration in 2007 to 23 percent by mid-2009; however, its broadband penetration is still at the modest 5 percent mark. The authors of the report find that in the last few years, operators and governments have begun to give priority to expanding Internet access and speed in these countries. In the third grouping, markets show a user penetration of less than 10 percent. War-ravaged Afghanistan, for instance, is managing 2 percent user penetration under extremely difficult circumstances. Whereas the Internet penetration rates in Japan and Korea are the highest in the world and, therefore, indicate that Internet access is widely available across the country, this assumption cannot be made for China. When we look at the penetration rate by Chinese regions a strong imbalance between its rural and urban areas can be ascertained. In the more urban regions in East China the penetration rate is substantially higher than in central or western China. This major constraint must be taken into account when we interpret the data that Google Insights for Search provides for China.

\section{Search engine market and Internet users}

As of 2012 on a global scale, Google is the uncontested leader on the search engine market. Google basically owns the market in Europe and Latin America but lags seriously behind in Asia with a market share of less than 50 percent in Japan, Hong Kong, China and Taiwan. In Korea, Google's share is only five percent, whereas the national search engine Naver controls the Korean market (Crampton 2008). However, the relatively low popularity level of Google among East Asian Internet users turns out to be a methodological asset rather than a constraint for our assessment of awareness of discrimination in East Asian societies. On the basis that Europeans, North Americans, and Latin Americans predominantly use Google for search requests, it can be assumed that they show the same preference for Google while they are residing in a foreign country. Likewise we can assume that a substantial share of foreigners from Europe, Latin America, and North America who are residing in East Asia use Google for search operations on the web. We can substantiate this assumption by comparing the regional distribution of foreigners in the provinces of Japan, Korea and China with the regional distribution of search requests for the term 'discrimination'. If there is a strong relation between both data sets, it indicates that foreigners residing in the respective countries were the actual Google users who were looking up information on discrimination. However, Google Insights for Search does not provide any personal information such as age, educational background or occupation of its users, which makes impossible the actual identification of HRST or other occupational groups who might experience discrimination in East Asian societies. 
Taking the above methodological limitations into account, Google Insights for Search fulfils the main purpose of this work: the comparison of awareness of tolerance and thus discrimination in the three major East Asian nations of Japan, Korea and China.

\section{Discrimination in Japan, Korea and China}

\section{Japan}

Through Google as shown in Figure 1 we are able to see the trend of search requests for 'discrimination' among users residing in Japan between 2003 and the end of August 2010. Apart from the years 2004 and 2005, which can be characterised by great fluctuations in the number of requests, the average interest in 'discrimination' on Google between 2004 and 2010 amounts to 49 on the normalised scale. The level of awareness of discrimination and tolerance respectively has declined slightly since 2004.

Figure 1 Interest in 'discrimination' over time:

January 1, 2004-October 28, 2010

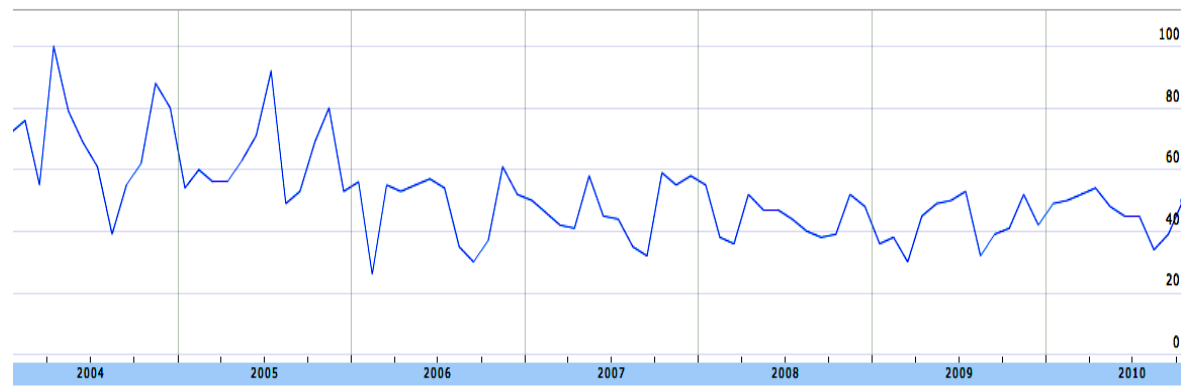

Note: The data are normalised and presented on a scale from $0-100 .{ }^{4}$

Source: Google Insights for Search. Author's compilation using Google Insights for Search.

Looking at Google's results on the regional level broken down by prefectures, we gain more insights into tolerance in Japanese society. Interestingly, users who were looking up information about discrimination were located in Japan's most populated prefectures, which indicates that discrimination issues tend to play a more important

4 The numbers on the graph reflect how many searches have been done for a particular term, relative to the total number of searches done on Google over time. They do not represent absolute search volume numbers because the data is normalised and presented on a scale from 0-100. Each point on the graph is divided by the highest point or 100. When Google does not have enough data, zero is shown. 
role in Japan's metropolitan areas, where more foreigners in general and HRST subjects in particular are likely to be found. In 2003, there were 1,915,030 registered foreigners in Japan, representing 1.5 percent of Japan's population of 127 million. Most foreigners live in the Kantō 関東, Chūbu 中部 and Kansai 関西 regions. Tōkyō 東京 has the highest percentage of foreigners (2.8 percent), followed by Ōsaka 大阪 (2.4 percent), Aichi 愛知 (2.3 percent), Kyōto 京都 (2.1 percent) and Mie 三重 (2.1 percent). The prefectures with the smallest proportion of foreigners are Hokkaidō 北海道 (0.3 percent), Kagoshima 鹿児島 (0.3 percent), Aomori 青森, Akita 秋田, Kumamoto 熊本 and Miyazaki 宮崎(all 0.4 percent) (Ministry of Internal Affairs and Communications 2010), and these do not show in Google's ranking in terms of regional interest.

Figure 2 Regional interest in 'discrimination':

January 1, 2004-October 28, 2010
1. Kyoto
2. Ibaraki
3. Tokyo
4. Hyogo
5. Kanagawa
6. Osaka
7. Chiba
8. Aichi
9. Fukuoka
10. Saitama

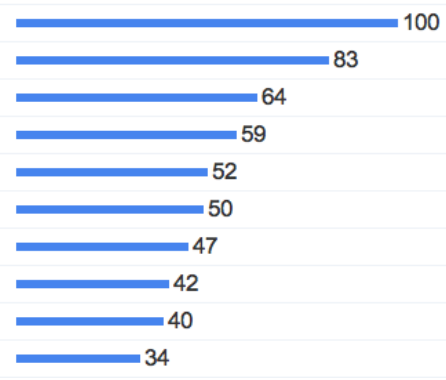

Note: The data are normalised and presented on a scale from 0-100.

Source: Google Insights for Search. Author's compilation using Google Insights for Search.

As shown in Figure 3, which lists the top searches for terms related to discrimination, three groups of issues can be identified in Japan: discrimination against other ethnicities, discrimination against women, and age discrimination. Google also provides information about which searches have been increasing in interest. These are 'age discrimination', 'discrimination against women', 'discrimination in Japan', and 'gender discrimination'. Since 2004, these search terms have experienced a change in growth greater than 5,000 percent, which suggests that women residing in Japanese society feel suppressed. 
Figure 3 Top searches 5 terms on 'discrimination':

January 1, 2004-October 28, 2010

1. japan discrimination

2. racial discrimination

3. women discrimination

4. discrimination in japan

5. age discrimination

6. discrimination against women

7. gender discrimination

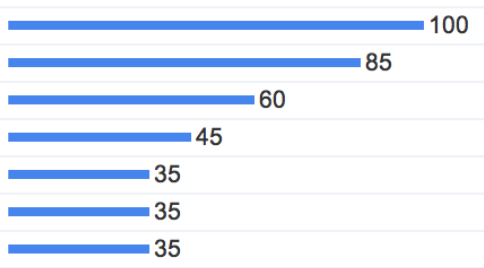

Note: The data are normalised and presented on a scale from 0-100.

Source: Google Insights for Search. Author's compilation using Google Insights for Search.

Through the application of Google Insights for Search, three main findings on discrimination and tolerance in Japanese society can be identified:

- The search interest for discrimination has decreased between 2004 and 2010.

- The awareness of discrimination is higher in more metropolitan areas.

- Awareness of discrimination against women is on the rise.

\section{Korea}

Whereas the interest of Internet users residing in Japan in discrimination issues does not show a great deal of fluctuation during each year, the ups and downs in Korea's case are quite substantial. Overall, the search interest in discrimination and tolerance issues in Korea seems to be considerably higher than in Japan. An average 59 on the normalised scale in comparison to the above-assessed 49 for Japan supports this claim. Two peaks in interest can be found in April 2005 and May 2006, and the lowest request for information on discrimination can be dated to September 2010. If we look at the search pattern for the 12 months between November 2009 and October 2010, the fluctuations come to light immediately. Whereas interest reached its peak in November 2009, it fell rapidly during December and January of the following year. In the course of the next months up to October 2010, the fluctuations were repeated but were not as large as in the winter months before. If we compare the charts on a yearly basis, they show no seasonal pattern.

5 The expression 'top searches' refers to search terms with the most significant level of interest. These terms are related to the term the user entered; if the user does not enter a search term, the top searches will be related to the category or country/territory the user has chosen. The system determines relativity by examining searches that have been conducted by a large group of users, preceding the search term the user has entered, as well as after. 
Figure 4 Interest in 'discrimination' over time:

1 January 2004-28 October 2010

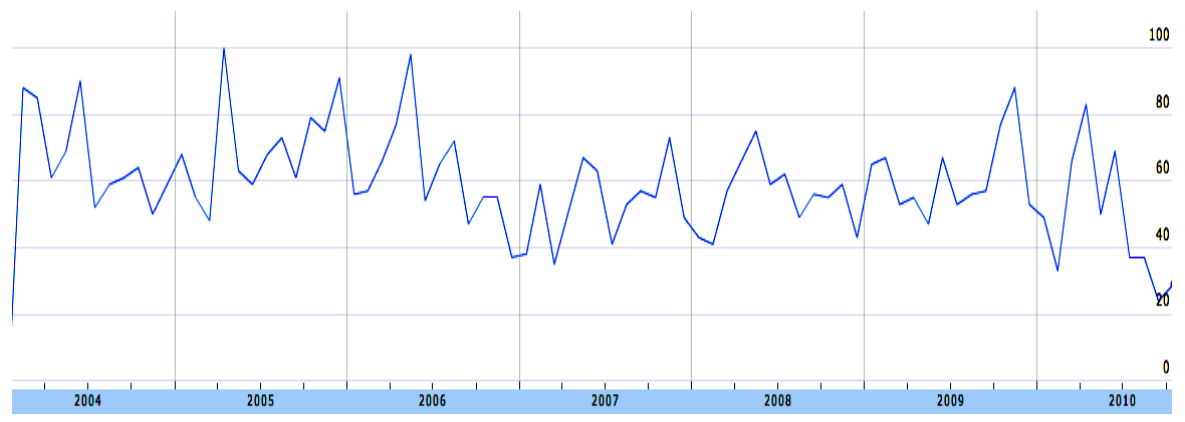

Note: The data are normalised and presented on a scale from 0-100.

Source: Google Insights for Search. Author's compilation using Google Insights for Search.

Looking at the results broken down by Korean regions and provinces respectively, it shows that Google users from only two Korean provinces spent a considerable amount of sending search requests to the Google mainframe. Not surprisingly, Korea's economic heartbeat Seoul 서울 is at the top of the list. Second and, therefore, placed last behind Seoul is the province Kyŏnggi-do 경기도, where 23 percent less interest was registered than in Seoul.

Figure 5 Top searches terms on 'discrimination':

January 1, 2004-October 28, 2010

1. Seoul City

2. Gyeonggi-do

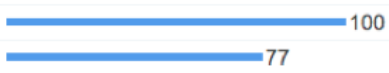

Note: The data are normalised and presented on a scale from 0-100.

Source: Google Insights for Search. Author's compilation using Google Insights for Search.

What can we learn from these results if we compare them with the numbers of registered foreigners living in Seoul and Kyŏnggi-do? According to a recent survey by the Seoul City government from 2009, foreigners account for 2.4 percent of the total population in Seoul (Park 2010). Foreigners numbered around 255,000 whereas Seoul's total population accounts for 10.45 million people. The numbers represent a ten-fold increase from the 51,000 registered in 1998. Chinese residents, by far, account for the largest share with 75.5 percent of the foreign population in Seoul, followed by Americans with 5.0 percent and Taiwanese with 3.5 percent. Japanese stood at 2.7 percent and Vietnamese at 1.8 percent. Broken down by labour and status respectively, the number of migrant manual workers stood at 58.5 percent, mar- 
ried immigrants at 11.6 percent, students at 7.8 percent and professionals at 4.1 percent. Whereas the number of foreigners living in Seoul has increased each quarter of the year since 2005, the figures decreased in May 2010 for the fourth consecutive quarter, mostly due to the declining population of ethnic Chinese, the Seoul metropolitan government announced on May 25, 2010. The number of foreigners had been increasing at an average of 18.11 percent a year until the preceding year. According to the officials, the decrease can be viewed as a reflection of the slowed domestic economy. Seoul is in the heart of Kyŏnggi-do province, but since 1946 has been a politically separate entity. Kyŏnggi-do is by far the most densely populated province in South Korea. With 48.5 million, the populations of Seoul, Inch'ŏn 인천 and Kyŏnggi-do make up almost half of the entire population residing in Korea (Statistics Korea 2010). Since the 1990s much has been invested in the building of satellite cities to absorb the demand for living space (Kim and Choe 1997: 192). Due to the lack of available housing in Seoul, many people decide to live in Kyŏnggi-do province, both natives and foreigners (Kim and Choe 1997: 192). In 2008, a total of 277,991 foreign residents were living in the province of Kyŏnggi-do, an increase of 29 percent from 2007 (Provincial Government of Gyeonggi-do 2011). They account for 2.5 percent of the total population of the province and 31.2 percent of the total foreign-resident population of the country $(891,341)$, making Kyŏnggi-do the province with the largest foreign-resident population. Between 1998 and 2008, the population increased by an annual average of 23,381 , and the rate of increase is expected to rise further in the coming years. When broken down by labour and status, workers, with a total number of 62.3 percent, account for the largest share. The number of immigrants by marriage and their children accounts for 50,526 people or 18.2 percent of the foreign population residing in Kyŏnggi-do. Students, language instructors and other foreigners are a less visible group than workers but still account for a considerable share, at 19.5 percent. Broken down by nationality, Chinese account for the largest proportion with 56.1 percent, followed by the Southeast Asian states, Vietnam, the Philippines, Thailand, Mongolia, and Indonesia. Men account for 58.3 percent while women make up 41.7 percent. Google's listing of Seoul City and Kyŏnggi-do as the only places from where a considerable number of search requests for discrimination were sent, corresponds with the actual numbers of foreigners living in both these areas. As noted before, most of the foreigners living in Korea are concentrated in these two areas. 
Figure 6 Top searches terms and breakouts ${ }^{6}$ on 'discrimination':

January 1, 2004-October 28, 2010

1. racial discrimination

2. gender discrimination

3. women discrimination

4. sexual discrimination

1. gender discrimination

2. racial discrimination

3. sexual discrimination

4. women discrimination

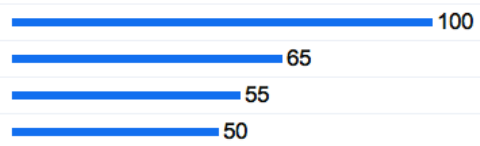

Breakout

Breakout

Breakout

Breakout

Note: The data are normalised and presented on a scale from 0-100.

Source: Google Insights for Search. Author's compilation using Google Insights for Search.

Looking at the top searches and so-called breakouts in Figure 6, which show a rise in interest of over 5,000 percent, a similar pattern between Korea and Japan can be diagnosed. In Korea as well in Japan, discrimination against other ethnic populations and women were the most frequently typed terms related to discrimination. One difference between Korea and Japan is that the issue of age discrimination does not seem to play as significant a role in Korea as it does in Japan, since it is listed neither in Korea's top searches nor in the breakouts. That 'racial discrimination' is listed at the top of the searches related to discrimination and has experienced an increase of over 5,000 percent in search requests since 2004, as have the semantically identical terms 'gender-, women- and sexual discrimination', indicates that Korea's awareness of discrimination did not rise and even declined in the course of the preceding six years.

To sum up, Google Insights for Search provides three main findings for the assessment of Korean society's tolerance level:

- The search interest for discrimination decreased between 2004 and 2010.

- The awareness of discrimination tended to be mainly an issue in Seoul City and the province of Kyŏnggi-do.

- Discrimination against women is perceived to be on the rise.

6 'Breakout' indicates that the search term has experienced a change in growth greater than 5,000 percent. 


\section{China}

The graph in Figure 7, showing the interest level in issues related to discrimination by users residing in China, is, compared to Japan's and Korea's, probably the most remarkable one. A number of repeating fluctuations appear throughout the period 2004-2010.

Figure 7 Interest in 'discrimination' over time:

January 1, 2004-October 28, 2010

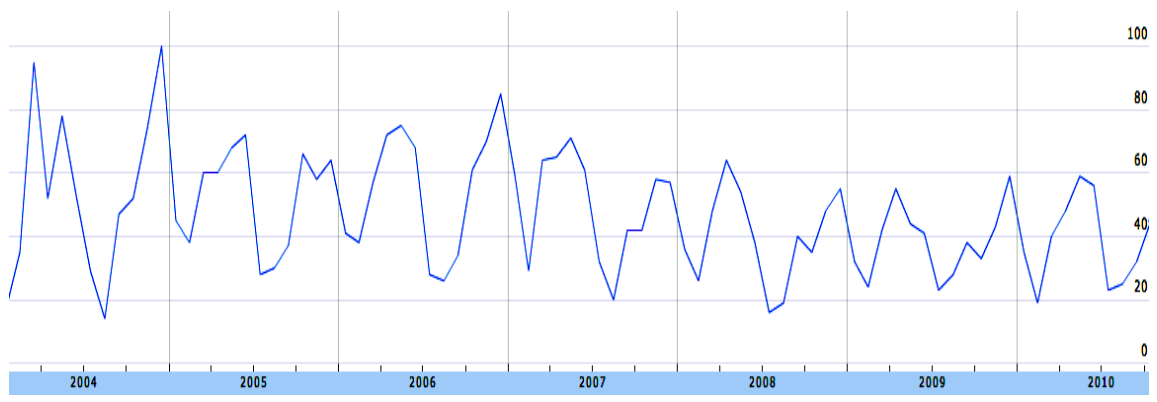

Note: The data are normalised and presented on a scale from 0-100.

Source: Google Insights for Search. Author's compilation using Google Insights for Search.

First, each year two main peaks can be identified clearly. The first one tends to happen in the second quarter of the year, during April or May. The second peak can be found without exception in December for the period 2004-2009. Looking at the right end of the graph, which ends with October 2010, the month in which this graph was requested, a clear tendency upwards is suggested, which indicates that the next peak will probably be seen in December 2010 as it was in all past years since 2004. Another striking pattern, showing the same degree of consistency, are the low points, marking a lower interest level among users residing in China who were looking up information for discrimination. Like the peaks, the low points are also two in number. They naturally follow in time before and after the high points. The first one tends to appear in the third quarter of each year, during the months July and August. The second low level in interest can be seen without a single exception in February of each year between 2004 and 2010. All in all, the fluctuations show a remarkably consistent pattern throughout the whole period, making a case of coincidence rather unlikely. On the contrary, the high level of consistency in the fluctuations in the course of each year indicates that systematic or structural factors could be responsible for the searching pattern among Google users in China. Looking at the specific months when the lowest and highest marks in the interest level occur, it appears that traditionally busy and work-intensive periods, on the one hand, and more relaxing 
times like holidays in the course of the year, on the other hand, are responsible for this pattern. For instance, during the days of the Chinese New Year festival, which is the most important of the traditional Chinese holidays, the bottoms of the graph always appear in February, which is the exact period of time when the Chinese New Year festival is under way. Likewise, during July and August, when children, students and families tend to go on holiday, the interest level in searching for information about discrimination on the web is significantly lower. Complementary to this pattern, the interest level reaches its peak during April/May and without exception in December, periods that are characterised by intensive work.

What conclusions can we draw from this? On the assumption that search requests for discrimination in the web depend on seasonal factors such as holidays, does this mean that people feel less discriminated against during holidays and more discriminated against during periods of intense work? This hypothesis holds true to the extent that the probability of being discriminated against rises with the number of personal interactions a person has within his or her social environment. Naturally, this is true for periods when people work or study. This hypothesis appears even more likely when we compare the social setting in times of holidays and periods of work. During holidays, people tend to visit their families and extended families. In such a social environment, feelings related to discrimination are more likely to happen at work than they are with family members.

However, looking solely at the pattern in search interest in discrimination over time does not provide any information about the users residing in China. Our purpose of finding indications that the requests related to discrimination sent to Google were possibly coming from foreigners is hard to achieve because of the scarce availability of data on foreigners and immigrants at the provincial level in China. In order to find potential relations between the number of requests related to discrimination and other factors on the provincial level, we must take a look at a number of available data sets for those provinces that Google has identified as more interested in issues related to discrimination. 
Figure 8 Regional interest in 'discrimination':

January 1, 2004-October 28, 2010

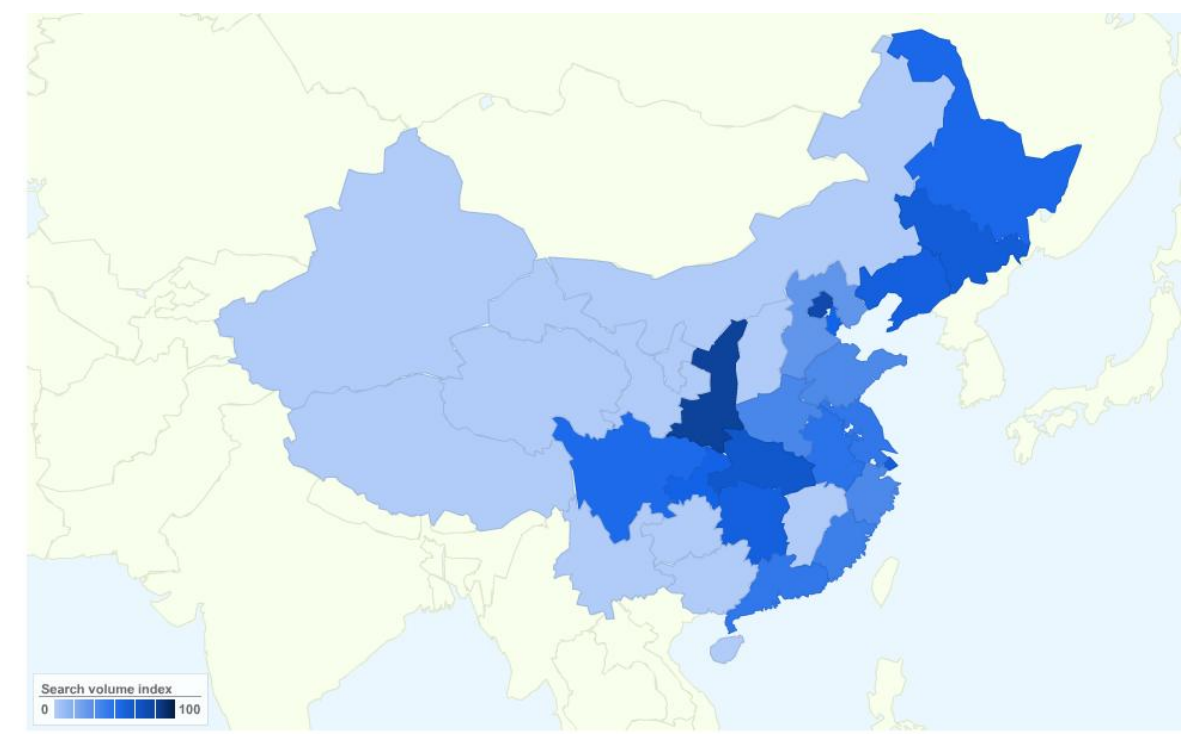

Note: The data are normalised and presented on a scale from 0-100.

Source: Google Insights for Search. Author's compilation using Google Insights for Search.

Unlike Korea, where a considerable number of requests were sent from only two regions, the interest in discrimination in China is regionally more distributed than in Korea. The requests are heavily concentrated in central and southeast China and along the east coast of China. The distribution of research requests across China basically reflects the current per capita income disparities between regions. Economic development has generally been more rapid in coastal areas than in the interior. The three wealthiest regions lie along the southeast coast, the east coast, and around the Bóhăi Sea 渤海, in the Běijīng-Tiānjīn-Liáoníng area 北京-天津-辽宁. The province of Shănxī 陕西 in the central north of China is listed at the top, followed by Běijīng, which shows just 8.0 percent less interest in issues of discrimination. The other eight listed provinces stand relatively close to each other in terms of search interest. Taking the main constraint of unequal distribution of Internet access as well as the lower search engine market share of Google in China into account, we can conclude that Google is used more in the developed regions of China. Whether foreigners were actually looking for information about discrimination or not, may be answered by the list of top searches. 
Figure 9 Top searches terms and breakouts on 'discrimination':

January 1, 2004-October 28, 2010

\begin{tabular}{|c|c|}
\hline 1. racial & 100 \\
\hline 2. racial discrimination & -100 \\
\hline 3. 歧视 (discrimination) & -65 \\
\hline 4. gender & -55 \\
\hline 5. gender discrimination & 50 \\
\hline 6. discrimination women & 35 \\
\hline 7. sexual discrimination & 35 \\
\hline 8. discrimination in china & 30 \\
\hline 9. price discrimination & 30 \\
\hline 10. employment discrimination & -25 \\
\hline 1. discrimination analysis & Breakout \\
\hline 2. discrimination in america & Breakout \\
\hline 3. discrimination law & Breakout \\
\hline 4. discrimination 翻译 (translation) & Breakout \\
\hline 5. price discrimination & Breakout \\
\hline 6. race discrimination & Breakout \\
\hline 7. social discrimination & Breakout \\
\hline 8. 种族歧视 (racial discrimination) & Breakout \\
\hline 9. gender & $+170 \%$ \\
\hline 10. gender discrimination & $+150 \%$ \\
\hline
\end{tabular}

Note: The data are normalised and presented on a scale from 0-100.

Source: Google Insights for Search. Author's compilation using Google Insights for Search.

Besides the central terms 'racial and gender discrimination', which were most frequently requested in China as they were in Korea and Japan, one obvious difference in China's top searches is the fact that a considerable number of searches were also typed in Chinese characters, as shown in Figure 9. The fact that qíshi 歧视, the Chinese translation for discrimination is ranked at position 3 among top searches can be interpreted to the extent that members of ethnic minorities who are naturally native Chinese speakers are facing discrimination and therefore use Google to get information on this issue. However, it could also just be the fact that this translation was used by Chinese-speaking social scientists who were conducting desk research. This assumption becomes more substantive if we look at the breakouts, describing terms that have risen in popularity by over 5,000 percent for the period 2004-2010. The first two listed breakouts, 'discrimination analysis' and 'discrimination in America', are supporting signs for this claim. In contrast to Japan and Korea, issues of gender discrimination and discrimination against women respectively have not grown as fast in interest among Google users in China as those using Google in Japan or Korea. 
Overall, Google Insights for Search provides three main findings for the assessment of Chinese society's tolerance level:

- The awareness of discrimination seems to have declined since 2004, at least for the more developed provinces in China.

- The distribution of search requests for discrimination across China is concentrated in central and southeast China and along the east coast of China. This result reflects the current per capita income disparities between regions and various Internet penetration rates across China.

- The awareness of discrimination against women has risen but not as strongly as in Japan and Korea.

\section{Analysis}

\section{Japan}

Despite the fact that Japan is still at the forefront in the S\&T field (OECD 2008a: 132), the demographic trends in combination with the alarming shortage of HRST elements (MEXT 2003), make it only a matter of time until Japan loses its dominant position. Japan is also a leading country in terms of investment intensity in S\&T, but the output has been rather mixed (OECD 2008a: 132). Besides structural factors such as the low degree of interlinkages between industry and research institutes, the low level of international co-operation between Japanese researchers and their foreign colleagues has been identified as an essential reason for the rather disappointing results in some areas (OECD 2008a: 133). In terms of HRST, although Japan's share of university graduates is one of the highest among advanced countries, the share of HRST subjects in total employments is below the OECD average. Likewise, Japan does not utilise its female workforce adequately. The proportion of women receiving degrees from S\&T fields of studies, as well the share of female HRST subjects employed in S\&T, are among the lowest in the OECD (OECD 2009a). Japan's internationalisation efforts in the higher education sector have gained momentum, but still, the share of international students is far below the OECD average. The low proportion of foreign faculty members contributes to the still dominant national character of Japan's research environment. Complementary to that, a number of substantial barriers still exist, such as language, a high level of prices for goods and services, or difficulties in daily life for family members that make Japan a less attractive place to work and live (MEXT 2003). In terms of tolerance, Japan's awareness of discrimination has declined slightly since 2004. Furthermore, issues related to discrimination seem to be more relevant in metropolitan areas with higher shares of foreigners, 
which indicates that foreigners are the actual users searching for information on discrimination. Looking at the top searches and breakouts, terms that have risen in interest over 5,000 percent since 2004 show that discrimination against foreigners, ethnic minorities, and women is on the rise.

All in all, the findings that Google provides on tolerance and discrimination correspond with the results of independent reports on Japan's performance in S\&T: Japan's rather disappointing outcomes in S\&T are due not to inadequate input intensity but to Japan's low ability to attract international global HRST, a failing that is rooted in unequal opportunities for women in general and in particular for foreign HRST within Japan's innovation system. Referring back to the definition of discrimination, Japan still seems to exclude certain individuals and groups of people on the basis of their differing cultural background and/or gender. From these observations, we can conclude that there is a rather robust relationship between Japan's ability to attract global HRST and its low tolerance towards foreigners.

\section{Korea}

Overall, Korea has demonstrated its reputation as a country associated with the East Asian miracle. Similarly to Japan, Korea is one of the leading countries in R\&D intensity and has performed exceptionally well in a number of areas in which it is regarded as the leading country, such as information and communications technology (OECD 2009b: 111). But, as in Japan, with respect to high investments, the outcome has not been satisfying in all areas, which again can partly be attributed to the low level of international collaboration (OECD 2008a: 135). The high numbers of graduates in science and engineering majors may indicate that Korea does not need to rely on the capacities of foreign HRST, but this conclusion proves to be wrong to the extent that Korea's innovation system would seem, rather, to need more graduates at the M.A. and Ph.D. levels than the current oversupply of basic college graduates could possibly compensate for (OECD 2009b: 24). In Japan, the number of incoming students and foreign HRST is likewise relatively low, but in contrast to Japan, the outflow of Korean students, especially to the United States, is substantially higher (OECD 2009b: 163). Although these students represent a tremendous potential for Korea's S\&T sectors, Korea is not able to tap it, owing to the unwillingness of Korean HRST to return to Korea at least for the first few years following their graduation (United States National Science Foundation 2004). Following this trend, Korea also lacks the ability to import foreign expertise (OECD 2007: 248). Currently, Korea is in danger of seeing its native science base deteriorate. In order to prevent this, the Korean government has started a number of initiatives to attract both students and world-class researchers, that include preferential visa programmes for foreign HRST applicants (Park 2007). In terms of tolerance, issues related to 
discrimination seem to be more severe than in Japan. The comparison between the regional distribution of requests, on the one hand, and the share of foreigners living in Korean provinces, on the other, shows that in the two most densely populated regions in which the majority of foreigners live, Seoul and Kyŏnggi-do, the level of awareness of discrimination seems to be the highest in Korea. In terms of top searches and breakouts, interest in racial and gender discrimination has risen more than five-hundred-fold for the period since 2004.

In summary, the findings we gained by applying Google Insights for Search substantiate the hypothesis that foreigners are likely to look for information on Google if they are confronted with discrimination. The fact that Google's share in the search engine market in Korea accounts for a modest 5.0 percent, together with the phenomenon that Google's displayed regional distribution comes only from the two most densely populated regions in which most foreigners live, make Google a reliable tool in displaying foreigner's frustration about discrimination in Korea.

\section{China}

Until recently, China's development of its scientific and technological capabilities had difficulty in keeping pace with its rapid economic development in the last decades, but this has changed (OECD 2008a: 32). China has invested heavily in S\&T and is following a more aggressive and open strategy than Korea or Japan (Sachs and Woo 1993: 139-141; Qian and Xu 2007: 135-70). In absolute numbers, China performs quite well, but in relative terms is still below the OECD average. Whereas the number of researchers in China is the second highest in the world, second only to the United States, where more researchers conduct their work, the share of HRST in the total Chinese population is far below the average of advanced countries (OECD 2008b: 52). Similarly to its neighbours, China's output productivity in terms of scientific paper publications and patent applications from its native HRST sector has not reached the leading benchmark level ( $\mathrm{Lu} 2010$ : 120). More worrisome for China is the fact that the number of science and engineering degrees in its tertiary educational system has been falling since 2000 (OECD 2008a: 52), which is likely to intensify tensions within the Chinese innovation system. Basically, China has invested heavily in the development of capital-intensive technological infrastructure, but the growth of HRST has not grown as quickly. Although undergraduate and graduate enrolments in the science and engineering fields are higher than the OECD average, severe human capital shortage still exists in S\&T (OECD 2008a: 47). One major strategy the central and local governments are pursuing is to attract a large number of Chinese HRST elements who are currently working and studying abroad (Saxenian 2003: 24). In order to attract both foreign and Chinese HRST, China needs to establish an attractive working and living environment, which supports people de- 
veloping their talents. In terms of awareness of discrimination and tolerance, the awareness of tolerance seems to have improved, at least in those provinces where a considerable number of Google users exist. One major discovery that has been made possible through Google Insights for Search is that the level of discrimination depends on seasonal and annually occurring periods such as holidays and workintensive periods. During holidays, the number of search requests for discrimination is clearly lower than in times when people are typically busy working. The regional distribution of requests corresponds with the degree of development in Chinese provinces. Requests from Google users tend to be more frequent in central and eastern China.

All in all, it seems that the issue of tolerance and discrimination towards foreign HRST in China is less severe than in Korea or Japan. The trend whereby the overall level of search requests for discrimination has decreased since 2004 supports this claim. Furthermore, the whole economy in general and the innovation system in particular is wide open for foreign and overseas Chinese HRST. In order to ensure and extend the national absorptive capacities that are essential for technological transfer from abroad, China needs to intensify its efforts in accelerating the production of highly educated home-grown talent, while maintaining the quality of its graduates

\section{Conclusion}

The application of Google Insights for Search was an attempt to measure and quantify social phenomena such as the awareness of tolerance and discrimination. In the face of the still inadequate working and living environments identified for foreign HRST and the as yet unimproved situation on discrimination against foreigners, the central hypothesis of this work suggests that due to the lack of tolerance in East Asian societies, global talents and highly qualified foreigners choose to live and work in more tolerant places, outside of East Asia.

This has been proven to be true to the extent that the considerable level of discrimination against foreigners might have contributed, among other factors, to a less attractive working and living environment in East Asian societies. The specific extent and level of the actual tolerance levels in Japan, Korea and China could not be measured by using Google Insights for Search. However, with such a current status, the economic and, in particular, social costs of moving to East Asia, either alone or with family, seem to be too high for foreign HRST elements. In the presence of this finding, how can the already initiated policy measures in attracting global talent be evaluated? Basically, the East Asian governments have concentrated predominantly only on improving working conditions for HRST incomers but have paid insufficient attention to the improvement of the living environment in general and to the establishment of an open and tolerant society in particular. As long the East Asian 
governments fail to initiate measures for educating the public about the benefits and urgency of intercultural understanding and openness and tolerance towards foreign cultures, discriminative behaviour among Koreans, Japanese, and Chinese will continue to exist. 


\section{REFERENCES}

Askitas, Nikolaos, and Klaus F. Zimmermann. "Google Econometrics and Unemployment Forecasting,” 2009, http://ftp.iza.org/dp4201.pdf, accessed October 2012

Azad, Sandir. "Discrimination Towards Foreigners in Japan.” In Global Politician 2006, http://web.archive.org/web/20100129194517/http://globalpolitician.com/22348-japan-race, accessed October 2012

Batolova, Jeanne, and Lindsay Lowell. "The Best and the Brightest: Immigrant Professionals in the U.S." In The Human Face of Global Mobility, edited by Michael Peter Smith, and Adrian Favell. New Jersey: Rutgers State University, 2006

Benda, Ernst. "Verständigungsversuche über die Würde des Menschen." In Neue Juristische Wochenschrift, 54, 2001 2147-2148

Bhagat, Rabi S. "The Rise of the Creative Class: And How It's Transforming Work, Leisure, Community, and Everyday Life by Richard Florida." In Administrative Science Quarterly, 49/2, 2004, pp. 321-25

Bouvier, Leon. F., and David Simcox. "Foreign-Born Professionals in the United States." In Population and Environment, 5, May 1995, pp. 429-444

Crampton, Thomas. “Google's Tiny Market Share of Search in Asia.” March 19, 2008, http://www.thomascrampton.com/media/googles-tiny-market-share-of-search-in-asia/, accessed October 2012

Evans, Peter, and Lisa Hulme-Jones. "Executive Summary.” In 2009 Asian Internet Market. http://www.budde.com.au/Research/2009-Asian-Internet-Market.html\#execsummary, accessed October 2012

Florida, Richard. The Rise of the Creative Class: And How It's Transforming Work, Leisure, Community and Everyday Life. New York: Basic Books, 2004

Florida, Richard. Cities and the Creative Class. New York: Routledge, 2005a

Florida, Richard. The Flight of the Creative Class. The New Global Competition for Talent. New York: Harper Collins, 2005b

Florida, Richard, Charlotta Mellander and Haifeng Qian. "Creative China? The University, Human Capital and the Creative Class in Chinese Regional Development." 2008, http://martinprosperity.org/media/creative_china_october_2008.pdf, accessed October 2012

Florida, Richard. "Korea's need for the X factor. Global perspectives for the next decade.” 2010, http://koreajoongangdaily.joinsmsn.com/news/article/article. aspx?aid=2920636, accessed October 2012

Forst, Rainer. Toleranz im Konflikt. Frankfurt: Suhrkamp, 2003

Giddens, Anthony, Mitchell Duneier, Richard P. Appelbaum, and Deborah Carr. Introduction to Sociology 7th Ed. New York: W.W. Norton, 2009

Glionna, John M. "Trying to Teach South Korea about Discrimination.” Los Angeles Times, February 24, 2009, http://articles.latimes.com/2009/feb/24/world/fg-korea-teach24, accessed October 2012

Google. "How does Google Insights for Search work?" http://support.google.com/adwords/agency/bin/answer.py?hl=en\&answer=87276, accessed August 2010

Hoffman, Donna. L., and Thomas P. Novak. "Are Brand Attitudes Contagious? Consumer Response to Organic Search Trends.” 2009, http://www.nd.edu/ markdept/020812/sss/BrandAttitudesContagiousLongAbstractNov2009.p df, accessed August 2010

Jia, Hepeng. "Female Scientists Face Discrimination in China." In SciDevNet, March 8, 2007 
Kim, Joochul, and Choe Sang-Chuel. Seoul: The Making of A Metropolis. New Jersey: John Wiley

Letzing, John. "IMF Sees East Asia Economies Surpassing Euro Zone.” In Wall Street Journal, November 3, 2009, http://articles.marketwatch.com/2009-11-03/markets/30769557_1_eurozone-japan-s-gdp-international-monetary-fund-forecast, accessed October 2012

Lu, Jinxiu. "Scientific Publication in China: An Overview and Some Thoughts on Improvement." In Science Editor, 4, 2010, pp. 120-121

Lucas, Robert E. "On the Mechanics of Economic Development." In Journal of Monetary Economics, 22, 1988, pp. 3-42

McGregor, Eugene B., Jr. "The Flight of the Creative Class: The New Global Competition for Talent; The New Division of Labor: How Computers Are Creating the next Job Market; The State of Working America." In Journal of Policy Analysis and Management 25/3, 2006, pp. 741-52.

MEXT (Ministry of Education, Culture, Sports, Science and Technology). "White Paper on Science and Technology 2003." 2003, http://www.mext.go.jp/b_menu/hakusho/html/hpag200301/index.html, accessed October 2012

Ministry of Internal Affairs and Communications: Statistics Bureau. "2010 Population Census." http://www.stat.go.jp/english/data/kokusei/index.htm, accessed October 2012

Moroder, Barbara. "International Mobility of Highly Skilled Professionals." MA diss., University of Salzburg, 2001

Müller, Max, and Alois Halder. Kleines philosophisches Wörterbuch. Freiburg: Herder, 1973

Naylor, Ted D. "The Rise of the Creative Class: And How It's Transforming Work, Leisure, Community and Everyday Life. The Flight of the Creative Class: The New Global Competi tion for Talent by Richard Florida." In Canadian Public Policy/Analyse De Politiques, 29/3, 2003, pp. 378-79.

Nelson, Todd D. Ageism: Stereotyping and Prejudice against Older Persons. Cambridge MA: MIT Press, 2002

Niccolai, James. "Google Invests in Firm that Tries to Predict the Future.” Reuters, May 3, 2010, http://www.reuters.com/article/2010/05/04/urnidgns852573c40069388088257718007bidUS149677852720100504, accessed October 2012

OECD (Organization for Economic Co-operation and Development). "The Measurement of Scientific and Technological Activities: Manual on the Measurement of Human Resources Devoted to S\&T." Paris: OECD Publications, 1995

OECD. "Economic Surveys - Korea." OECD Policy Brief, Paris: OECD Publications, 2007

OECD. “OECD Science, Technology and Industry Outlook 2008.” Paris: OECD Publications, $2008 \mathrm{a}$

OECD. "OECD Reviews of Innovation Policy China." Paris: OECD Publications, 2008b

OECD. “OECD Science, Technology and Industry Scoreboard 2009: Japan Highlights.” Paris: OECD Publications, 2009a

OECD. "OECD Reviews of Innovation Policy Korea." Paris: OECD Publications, 2009b

Park, Chung-a. "Foreign population in Seoul continue to dwindle." The Korea Times, May 25, 2010

Park, Myungsoo. "Policy Approach for Enhancing the International Mobility of Researchers: The Korean Case." PowerPoint presentation, OECD Workshop on the International Mobility of Researchers, Paris, March 28, 2007, http://www.koreatimes.co.kr/www/news/nation/2010/07/113_66455.html, accessed October 2012 
Provincial Government of Gyeonggi-Do. "Status of Foreign Residents in Gyeonggi Province," 2011.http://english.gg.go.kr/global/contents.do?lang=ENG\&pageCode=3710\#policy03, accessed October 2012

Qian, Yingyi, and Xu Cheng-Gang. "Why China's Economic Reforms Differ: The M-Form Hierarchy and Entry/Expansion of the Nonstate Sector." In The Economics of Transition, 2, June 2007, pp. 135-70

Sachs, Jeffrey, and Woo Wing Thye. "Structural Factors in the Economic Reforms of China, Eastern Europe and the Former Soviet Union." In Economic Policy Panel Meeting. Brussels, October 22-23, 1993, pp. 102-145

Salmenhaara, Perttu. "The Flight of the Creative Class." Book review, Acta Sociologica, 49/2, 2006 , pp. 234-35

Saxenian, Anna Lee. "Brain Circulation and Capitalist Dynamics: The Silicon Valley-HsinchuShanghai Triangle." CSES Working Paper Series No. 8, Center for Economy and Society, Department of Sociology, Cornell University, 2003.

http://www.economyandsociety.org/publications/wp8.pdf, accessed October 2012

Scharkow, Michael, and Jens Vogelgesang. "Google Insights for Search: A Methodological Innovation in the Study of the Public Agenda?" 2009, http://underused.org/docs/google_scharkow_vogelgesang2009.pdf, accessed October 2012

Schreiner, Klaus, and Gerhard Besier. "Toleranz. "In Geschichtliche Grundbegriffe. Historisches Lexikon zur politischen-sozialen Sprache in Deutschland VI, edited by O. Brunner et al., Stuttgart: E. Klett, 1997, pp.446

Shimizu, Kaho. "Middle Aged Job Seekers Facing Age Discrimination.” In Japan Times, February 6, 2002, http://www.japantimes.co.jp/text/nn20020206b4.html, accessed October 2012

Solow, Robert M. “A Contribution to the Theory of Economic Growth.” In Quarterly Journal of Economics, 1, February 1956, pp. 65-94

Statistics Korea. "Population Census." http://kostat.go.kr/portal/english/surveyOutlines/1/6/index.static, accessed October 2012

Suro, Roberto. "Commentary on the Cheskin Added Value/The Futures Company Study of Cultural Openness.” Added Value, January 18th, 2011, http://www.added-value.com/source/ 2011/01/roberto-suros-commentary-on-cultural-openness/, accessed October 2012

Teichert, Dieter. “Toleranz.” In Enzyklopädie Philosophie und Wissenschaftstheorie 4, edited by J. Mittelstraß, Stuttgart: Metzler, 1996

United States National Science Foundation. "Survey of Earned Doctorates." 2004, http://www.nsf.gov/statistics/seind04/c2/c2s4.htm\#c2s411, accessed October 2012

United Nations Global Teaching and Learning Project. "Understanding Discrimination." http://cyberschoolbus.un.org/discrim/id_8_ud_print.asp, accessed October 2012

Wang, Fengyan. "Confucian Thinking in Traditional Moral Education: Key Ideas and Fundamental Features." In Journal of Moral Education, 33/4, 2004, pp. 429-47 


\section{GLOSSARY}

\begin{tabular}{|c|c|c|}
\hline Aichi & 愛知 & prefecture in the Chūbu region \\
\hline Akita & 秋田 & prefecture located in the Tōhoku region in northern Honshū \\
\hline Aomori & 青森 & prefecture located in the Tōhoku region \\
\hline Běijīng & 北京 & capital of China, located in the northeast China plain \\
\hline Bóhăi & 渤海 & $\begin{array}{l}\text { the Bóhăi Sea forms the innermost gulf of the Yellow Sea } \\
\text { off the coast of northeastern and north China }\end{array}$ \\
\hline Chiba & 千葉 & $\begin{array}{l}\text { prefecture located in the Kantō region and the Greater } \\
\text { Tōkyō area }\end{array}$ \\
\hline Chūbu & 中部 & central region of Honshū, Japan's main island \\
\hline fānyì & 翻译 & translation \\
\hline Fukuoka & 福岡 & $\begin{array}{l}\text { prefecture situated on the northern shore of the island of } \\
\text { Kyūshū }\end{array}$ \\
\hline Hokkaidō & 北海道 & Japan's second largest island \\
\hline Hyōgo & 兵庫 & prefecture located in the Kansai region on Honshū island \\
\hline Ibaraki & 茨城 & $\begin{array}{l}\text { prefecture, located in the Kantō region on the main island } \\
\text { of Honshū }\end{array}$ \\
\hline Inch“ŏn & 인천 & city located in northwestern South Korea \\
\hline Kagoshima & 鹿児島 & $\begin{array}{l}\text { capital city of Kagoshima Prefecture at the southwestern tip } \\
\text { of the island of Kyūshū }\end{array}$ \\
\hline Kansai & 関西 & geographical area of Honshū \\
\hline Kantō & 関東 & geographical area of Honshū \\
\hline Kumamoto & 熊本 & $\begin{array}{l}\text { capital city of Kumamoto Prefecture on the island of } \\
\text { Kyūshū }\end{array}$ \\
\hline Kyŏnggi-do & 경기도 & province in Northern South Korea \\
\hline Kyōto & 京都 & $\begin{array}{l}\text { capital of the prefecture of Kyōto, located in the central part } \\
\text { of Honshū island }\end{array}$ \\
\hline Liáoníng & 辽宁 & province in the northeast of China \\
\hline Mie & 三重 & prefecture located in the Kansai region \\
\hline Miyazaki & 宮崎 & $\begin{array}{l}\text { capital city of Miyazaki Prefecture on the island of Kyūshū } \\
\text { in Japan }\end{array}$ \\
\hline Ōsaka & 大阪 & major city in the Kansai region \\
\hline qíshì & 歧视 & discrimination \\
\hline Seoul & 서울 & $\begin{array}{l}\text { Sŏul, capital of South Korea, located in the centre of } \\
\text { Kyŏnggi-do province }\end{array}$ \\
\hline Shànghăi & 上海 & major city, located at China's eastern coast \\
\hline Shănxī & 陕西 & province in northern China \\
\hline Tiānjīn & 天津 & $\begin{array}{l}\text { an urban agglomeration in the northeastern province of } \\
\text { Héběi at the Hǎihé river }\end{array}$ \\
\hline Tōkyō & & $\begin{array}{l}\text { capital of Japan, the centre of the Greater Tōkyō area and } \\
\text { the largest metropolitan area of Japan }\end{array}$ \\
\hline zhǒng zú qí shì & 灭歧视 & racial discrimination \\
\hline
\end{tabular}

